\title{
Genetic and virulence characterisation of Vibrio parahaemolyticus isolated from Indian coast
}

\author{
Divya Meparambu Prabhakaran', Thandavarayan Ramamurthy ${ }^{2}$ and Sabu Thomas ${ }^{1 *}$
}

\begin{abstract}
Background: V. parahaemolyticus is autochthonous to the marine environment and causes seafood-borne gastroenteritis in humans. Generally, $V$. parahaemolyticus recovered from the environment and/or seafood is thought to be non-pathogenic and the relationship between environmental isolates and acute diarrhoeal disease is poorly understood. In this study, we explored the virulence potential of environmental $V$. parahaemolyticus isolated from water, plankton and assorted seafood samples collected from the Indian coast.

Results: Twenty-two V. parahaemolyticus isolates from seafood harboured virulence associated genes encoding the thermostable-direct haemolysin (TDH), TDH-related haemolysin (TRH), and Type 3 secretion systems (T3SS) and 95.5\% of the toxigenic isolates had pandemic strain attributes (toxRS $/ \mathrm{new}^{+}$). Nine serovars, with pandemic strain traits were newly identified and an 04:K36 tdh $\mathrm{trh}^{+} \mathrm{V}$. parahaemolyticus bearing pandemic marker gene was recognised for the first time. Results obtained by reverse transcription PCR showed trh, T3SS1 and T3SS2 $\beta$ to be functional in the seafood isolates. Moreover, the environmental strains were cytotoxic and could invade Caco-2 cells upon infection as well as induce changes to the tight junction protein, ZO-1 and the actin cytoskeleton.

Conclusion: Our study provides evidence that environmental isolates of $V$. parahaemolyticus are potentially invasive and capable of eliciting pathogenic characteristics typical of clinical strains and present a potential health risk. We also demonstrate that virulence of this pathogen is highly complex and hence draws attention for the need to investigate more reliable virulence markers in order to distinguish the environmental and clinical isolates, which will be crucial for the pathogenomics and control of this pathogen.
\end{abstract}

Keywords: V. parahaemolyticus, Seafood, Pandemic traits, Type 3 secretion system, Pulsed-field gel electrophoresis, Cytotoxicity, Invasion

\section{Background}

Vibrio parahaemolyticus is a Gram-negative, halophilic bacterium that inhabits marine and estuarine environments. Since its discovery in 1950 as the causative agent of gastroenteritis in Japan [1], V. parahaemolyticus has become one of the leading causes of food-borne illness in humans. Infection is closely associated with the

\footnotetext{
* Correspondence: sabu@rgcb.res.in

${ }^{1}$ Cholera and Biofilm Research Lab, Department of Pathogen Biology, Rajiv Gandhi Centre for Biotechnology, Thiruvananthapuram, Kerala 695 014, India Full list of author information is available at the end of the article
}

consumption of raw or undercooked seafood, resulting in self-limiting diarrhoea [2]. Rarely, V. parahaemolyticus also causes wound infections and septicaemia [2]. The virulence of $V$. parahaemolyticus is associated with the production of thermostable-direct haemolysin (TDH) (encoded by $t d h$ gene) and/or TDH-related haemolysin (TRH, encoded by trh gene) as well as two type III secretion systems (T3SS) [3-5]. Two sets of the genes T3SS1 and T3SS2 are present on chromosomes 1 and 2, respectively [5]. 
Though a majority of clinical $V$. parahaemolyticus generally carry $t d h$ and/or trh, only a small proportion of environmental isolates have been found to harbour the hemolysin genes [6-8]. T3SS1 that produce cytotoxicity is present in all $V$. parahaemolyticus isolates irrespective of their source. T3SS2, on the other hand, is both cytotoxic and enterotoxic and has two phylogroups; T3SS $2 \alpha$ that co-localise with $t d h$ and T3SS2 $\beta$ found in association with trh [9]. The environmental population of $V$. parahaemolyticus is increasingly acquiring the virulence-related genes that classically define a clinical isolate $[10,11]$. However, the true pathogenic potential of such strains has not been evaluated at large.

After the emergence of the $V$. parahaemolyticus serovar O3:K6 in 1996 from Kolkata, India [12], infections caused by several serovariants, collectively called pandemic strains, have increased due to their global spread with several diarrhoeal epidemics [13]. The pandemic clone has the typical $t d h^{+} t r h^{-}$, tox $R S / \mathrm{new}^{+}$, orf $8^{+/-}$genotype, which is identified by Group-specific PCR (GSPCR) that detects the sequence variation in toxRS gene (toxRS/new) [14, 15]. The burden of $V$. parahaemolyticus diarrhoea is very high in Asian countries [16-18] and the outbreaks are related to raw shellfish consumption in the United States and Canada [19, 20]. In addition, sporadic outbreaks have been reported in coastal Europe [21, 22]. Although the pandemic strains are still prevalent in diarrhoeal cases in India [23], there is a paucity of information on $V$. parahaemolyticus from different environmental sources.

The aim of this study was to examine $V$. parahaemolyticus from environmental and seafood samples collected along the southern Indian coast for serogroup, putative virulence and their pathogenic potential on intestinal epithelial cell line.

\section{Results \\ Identification of $V$. parahaemolyticus from the environment}

Four hundred and seventeen $V$. parahaemolyticus isolates were identified from environmental and seafood samples collected through five districts of the coastal belt of Kerala during the sampling period. The highest recovery of the organism was from seafood $(225 / 417,53.9 \%)$ followed by water $(152 / 417,36.5 \%)$ and plankton $(40 / 417,9.6 \%)$. Environmental parameters such as temperature, $\mathrm{pH}$ and salinity were not checked during sampling, as the objective was focused mainly towards genetic profiling and pathogenic potential of $V$. parahaemolyticus.

\section{Distribution of virulence genes}

The isolates were screened for 22 virulence markers, including genes encoding haemolysins, T3SS1, T3SS $2 \alpha$, and T3SS $2 \beta$ and the pandemic strain marker of ORF-8 and group-specific PCR (GS-PCR). Twenty two (5.3\%) isolates were found to contain either of the haemolysins and were potentially toxigenic (Table 1); 19 had $t d h$ $\left(t d h^{+} t r h^{-}\right)$while 3 had $t r h\left(t d h^{-} t r h^{+}\right)$and all the isolates represented seafood $(22 / 225,9.8 \%)$. None were found to be $t d h^{+} t r h^{+}$.

The toxigenic isolates were then checked for T3SS genes coding for effectors and apparatus proteins. T3SS1 ( $v s c P$, vopS, vscK, $v s c F$ and $V P A 0450)$ was present in all the 22 isolates. Several genetic elements of T3SS $2 \alpha$ were detected with isolates harbouring more than three genes. While $\operatorname{vop} C$, thought to mediate invasion of nonphagocytic cells, was present in $19 t d h^{+} t r h^{-}$isolates, vopB2 was detected in $13, v s c C 2$ in $7, v o p T$, vopL and $v o p A / P$ in 5,9 and 6 isolates, respectively. Six of the isolates also harboured $v o p Z$, the gene responsible for intestinal colonisation and enterotoxocity. Genes encoding the T3SS2 $\beta$ ( $v s c C 2, v o p B 2, v s c S 2, v o p C, v o p A / P$ and vopL) were present in all the three $t d h^{-} t r h^{+}$isolates (Table 1). Twenty one isolates $\left(18 t d h^{+} t r h^{-}, 3 t d h^{-} t r h^{+}\right)$ belonged to the pandemic strain type $\left(\right.$ tox $\left.R S / \mathrm{new}^{+}\right)$.

\section{PFGE analysis of toxigenic strains}

The 22 toxigenic isolates consisted of 15 serovars with combinations of six $\mathrm{O}$ groups $(\mathrm{O} 1, \mathrm{O} 2, \mathrm{O} 3, \mathrm{O} 4, \mathrm{O} 5$ and O10) and nine different $\mathrm{K}$ types (K17, K19, K20, K23, K24, K25, K29, K36 and K42). The predominant serovar was O1:K25 $(n=4)$. Two $t d h^{-} t r h^{+}$isolates belonged to O3:KUT while the other was O4:K36.

Based on the serovar profile, a total of 15 isolates were analysed by PFGE and the pattern compared to an O3: K6 clinical isolate (NICED, Kolkata, India). The minimum genetic similarity of the isolates was $55 \%$ and fell into four distinct clusters (Fig. 1). Those that clustered together at 60\% similarity with the O3:K6 were isolates of O1:K19, O4:K29 (tdh $\left.t r h^{-}\right)$and O4:K36 $\left(t d h^{-} t r h^{+}\right)$ serovars. It was observed that isolates of the same O1: K25 serovar clustered differently. Likewise, the three $t d h^{-} t r h^{+}$isolates possessing identical virulence profiles were present in three different clusters. Interestingly, the GS-PCR positive and negative isolates clustered together. Overall, the results revealed a high genetic variability in environmental isolates of $V$. parahaemolyticus.

\section{Selection of strains for pathogenicity studies}

A total of 12 isolates of $V$. parahaemolyticus including 8 environmental and 4 clinical were included in downstream assays (Table 2). The environmental strains were selected based on the T3SS profile and serovar type.

\section{Expression of virulence genes}

Expression of virulence genes $t d h$, trh, effectors of T3SS1 (vopS, VPA0450), T3SS2 $\alpha$ (vopC, vopT, vopZ, $v o p A / P, v o p L)$ and T3SS2 $\beta(\operatorname{vop} C, \operatorname{vop} A / P, v o p L)$ was 
Table 1 Characteristics of 22 environmental $V$. parahaemolyticus isolates collected from the south-west coast of India

\begin{tabular}{|c|c|c|c|c|c|c|c|c|c|}
\hline Strain Id & Serotype & toxR & $t / h$ & $t d h$ & trh & toxRS/new & orf8 & T3SS2 genes & \\
\hline $\mathrm{H} 1$ & O1:K17 & + & + & + & - & + & - & vopC, vopT, vscC2, vopA, vopB2, vopL & T3Ss2a \\
\hline $\mathrm{H} 2$ & OUT:KUT & + & + & + & - & + & - & vopC, vopZ, vopL & \\
\hline H3 & O5:KUT & + & + & + & - & + & - & vopC, vopT, vscC2, vopA, vopB2 & \\
\hline $\mathrm{H} 4$ & O5:K17 & + & + & + & - & + & - & vopC, vopZ, vopA, vopL & \\
\hline H5 & 01:K19 & + & + & + & - & + & - & vopC, vopT & \\
\hline H6 & $\mathrm{O} 1: \mathrm{K} 25$ & + & + & + & - & + & - & vopC, vopT, vopZ & \\
\hline $\mathrm{H} 7$ & O1:K25 & + & + & + & - & - & - & vopC, vopT, vopZ & \\
\hline $\mathrm{H} 8$ & $\mathrm{O} 1: \mathrm{K} 23$ & + & + & + & - & + & - & vopC, vscC2, vopB2, vopL & \\
\hline H9 & O1:K25 & + & + & + & - & + & - & vopC, vscC2, vopB2, vopL & \\
\hline $\mathrm{H} 10$ & O5:K17 & + & + & + & - & + & - & vopC, vopZ, vscC2, vopA, vopB2 & \\
\hline $\mathrm{H} 11$ & O1:K25 & + & + & + & - & + & - & vopC, vopZ, vscC2 & \\
\hline $\mathrm{H} 12$ & O10:K24 & + & + & + & - & + & - & vopC, vopZ, vopB2 & \\
\hline $\mathrm{H} 13$ & O2:KUT & + & + & + & - & + & - & $\operatorname{vopC}, \operatorname{vopZ}, \operatorname{vop} B 2, \operatorname{vop} L$ & \\
\hline $\mathrm{H} 14$ & O4:K29 & + & + & + & - & + & - & vopC, vopZ, vscC2, vopB2, vopL & \\
\hline $\mathrm{H} 15$ & $\mathrm{O}: \mathrm{K} 17$ & + & + & + & - & + & - & vopC, vopB2 & \\
\hline $\mathrm{H} 16$ & O1:KUT & + & + & + & - & + & - & vopC, vopB2, vopL & \\
\hline $\mathrm{H} 17$ & O5:K20 & + & + & + & - & + & - & vopC, vopT, vopB2 & \\
\hline $\mathrm{H} 18$ & O5:K20 & + & + & + & - & + & - & vopC, vopA, vopB2 & \\
\hline H19 & O4:K42 & + & + & + & - & + & - & vopC, vopA, vopB2, vopL & \\
\hline $\mathrm{C} 12$ & O3:KUT & + & + & - & + & + & - & vscC2, vopB2, vscS2, vopC, vopA, vopL & $\mathrm{T} 3 \mathrm{SS} 2 \beta$ \\
\hline C13 & O3:KUT & + & + & - & + & + & - & vscC2, vopB2, vscS2, vopC, vopA, vopL & \\
\hline K23 & O4:K36 & + & + & - & + & + & - & vscC2, vopB2, vscS2, vopC, vopA, vopL & \\
\hline
\end{tabular}

determined by RT-PCR in relation to $\operatorname{gyr} B$, which is a constitutively expressed housekeeping gene. The $t d h$ gene was transcribed by all the $t d h^{+} t r h^{-}$clinical isolates, whereas inconsistent results were observed with the seafood isolates $\mathrm{H} 10, \mathrm{H} 12$ and $\mathrm{H} 14$. Either the bands were very faint or not detected at all in repeated PCRs. It was concluded that the $t d h$ gene was not functional in the seafood isolates. In contrast, the $t d h^{-} t r h^{+}$isolate $\mathrm{K} 23$ and its clinical counterpart ATCC17802 transcribed trh gene with the production of the corresponding amplified cDNA (Additional file 1: Figure S1).

The expression results were verified by the haemolytic activity of isolates on human RBC (Additional file 1: Figure S2). Both the $t d h$ - and trh-containing seafood strains showed extremely weak haemolytic activity $(\leq 5 \%)$ after $6 \mathrm{~h}$ of incubation, whereas the clinical isolates were $50 \%$ haemolytic after $6 \mathrm{~h}$, except ATCC17802 that could lyse only $3 \%$ of RBC. The haemolytic action of the seafood isolates showed only a modest increase when incubation was extended till $12 \mathrm{~h}$ while a dramatic rise (>90\%) was seen with $t d h^{+} t r h^{-}$clinical isolates except $t d h^{-} t r h^{+}$ATCC17802 (20\%).

All the selected seafood isolates irrespective of the toxin type, transcribed T3SS1 effectors indicating they are functional (Additional file 1: Figure S3). Prominent amplification of T3SS2 $\beta$ genes was also detected in the isolate K23 (Additional file 1: Figure S3). On the other hand, T3SS $2 \alpha$ effectors were not transcribed by any of the $t d h^{+} t r h^{-}$seafood isolates. Surprisingly, a faint band was detected for vop $V$ in the isolate H14, which was absent in the control RNA (Additional file 1: Figure S3). As expected, the clinical control isolates functionally expressed the T3SS genes.

\section{Cytotoxicity of environmental V. parahaemolyticus}

Cytotoxicity was tested by measuring the levels of cytoplasmic $\mathrm{LDH}$ released into the medium during infection of Caco-2. This release indicated the degree to which the integrity of host cell membrane was compromised. Only two clinical isolates, AP11243 $\left(t d h^{+} t r h^{-}\right)$and ATCC17802 $\left(t d h^{-} t r h^{+}\right)$were highly cytotoxic to Caco-2 cells (94\% and 93\%, respectively) while the reference strain RIMD2210633 showed a mean cytotoxicity of $8 \%$ (Fig. 2a). Among $t d h^{+}$trh $^{-}$seafood isolates, H10 and H12 showed good cytotoxicity (43\% and $34 \%$, respectively), whereas the isolate H14 was cytotoxic to $85 \%$ of cells, almost comparable to that of AP11243. The $t d h^{-} t r h^{+}$isolate K23 that had a fully functional T3SS exhibited low cytotoxic activity (15\%). Very low cytotoxic activity, ranging from 6 to 17\%, was shown by the four non-toxigenic 


\section{PFGE-NotI}

\section{PFGE-NotI}

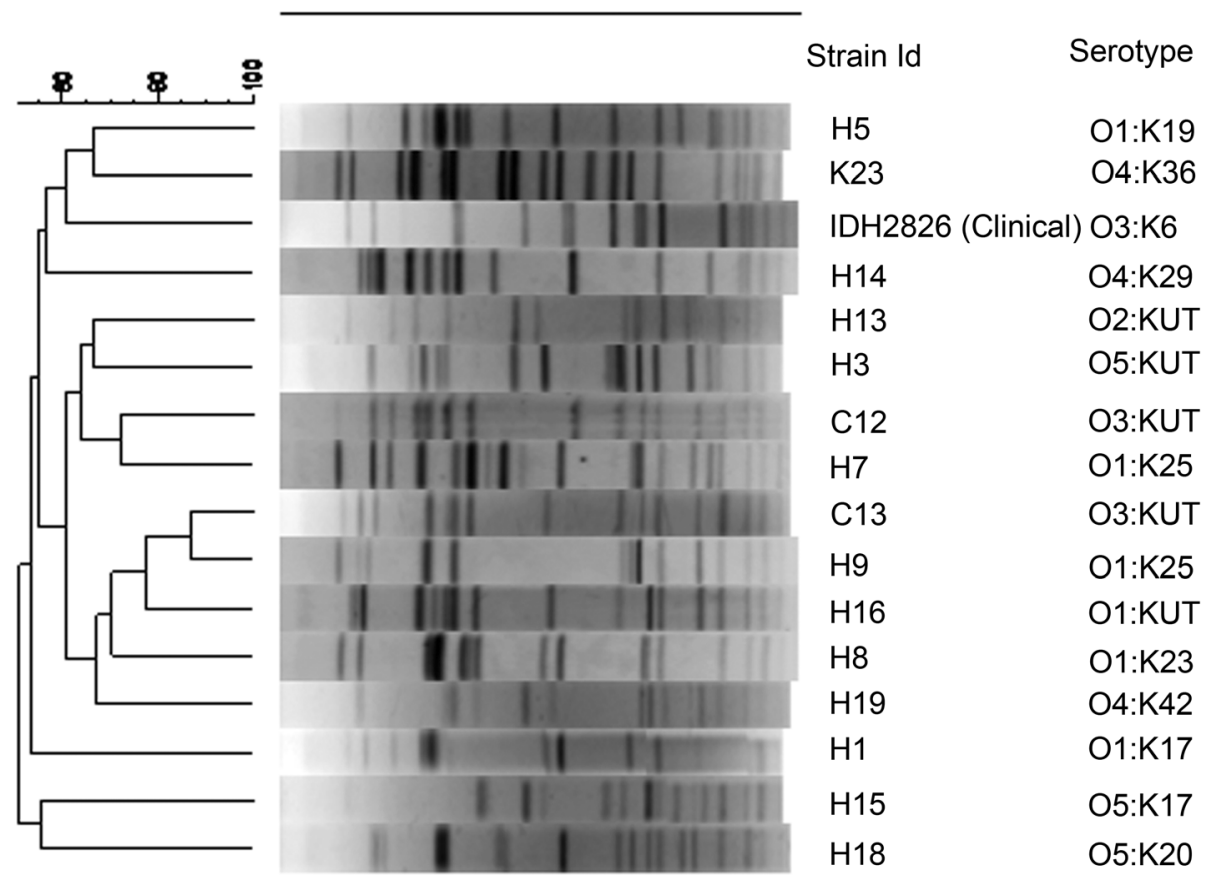

Fig. 1 Notl digested PFGE profile of $V$. parahaemolyticus with dendrogram. Clustering was performed using the unweighted pair group method (UPGMA) and the Dice correlation coefficient with a position tolerance of $1.0 \%$

isolates. However, when compared, the results between clinical, environmental toxigenic and non-toxigenic isolates were not statistically significant $(p>0.05$, one-way ANOVA). A time course analysis of LDH release by $t d h^{+} t r h^{-} \mathrm{H} 14$ and $t d h^{-} t r h^{+} \mathrm{K} 23$ was done up to $6 \mathrm{~h}$ postinfection. There was a constant increase in cytotoxicity for H14 with $100 \%$ cell lysis at $6 \mathrm{~h}$ while the cytotoxicity induced by K23 reached a peak at $4 \mathrm{~h}(15 \%)$ and slightly decreased thereafter (Fig. 2b).

\section{Adhesion and invasion}

$V$. parahaemolyticus contains several adhesins to promote attachment and subsequent colonization of host cells. Since it is a key event for the successful establishment of infection, ability of the environmental isolates to adhere to Caco-2 cells were determined and compared to the clinical isolates. The adhesion of the $V$. parahaemolyticus isolates to Caco-2 cells ranged from 8 to $28 \%$ (Table 3, Fig. 3a). All the $t d h^{+} t r h^{-}$clinical isolates showed

Table $2 \mathrm{~V}$. parahaemolyticus strains used for pathogenicity studies

\begin{tabular}{|c|c|c|c|c|}
\hline Group & Strain Id & Serogroup & Toxin Profile & Source \\
\hline \multirow[t]{4}{*}{ Environmental, toxigenic } & $\mathrm{H} 10$ & O5:K17 & $t d h^{+} t r h^{-}$ & \multirow[t]{4}{*}{ Present study, seafood } \\
\hline & $\mathrm{H} 12$ & O10:K24 & $t d h^{+} t r h^{-}$ & \\
\hline & $\mathrm{H} 14$ & O4:K29 & $t d h^{+} t r h^{-}$ & \\
\hline & K23 & O4:K36 & $t d h^{-} t r h^{+}$ & \\
\hline \multirow[t]{4}{*}{ Environmental, non-toxigenic } & AJM1 & O5:K17 & $t d h^{-} t r h^{-}$ & \multirow[t]{4}{*}{ Present study, water } \\
\hline & ME1 & O10:KUT & $t d h^{-} t r h^{-}$ & \\
\hline & ME4 & O1:K32 & $t d h^{-} t r h^{-}$ & \\
\hline & ME8 & O1:K32 & $t d h^{-} t r h^{-}$ & \\
\hline \multirow[t]{4}{*}{ Clinical } & RIMD2210633 & O3:K6 & $t d h^{+} t r h^{-}$ & Reference pandemic isolate, Japan \\
\hline & AP11243 & O1:KUT & $t d h^{+} t r h^{-}$ & Bangladesh \\
\hline & IDH03525 & O3:K6 & $t d h^{+} t r h^{-}$ & India \\
\hline & ATCC17802 & $\mathrm{O} 1: \mathrm{K} 1$ & $t d h^{-} t r h^{+}$ & Japan \\
\hline
\end{tabular}




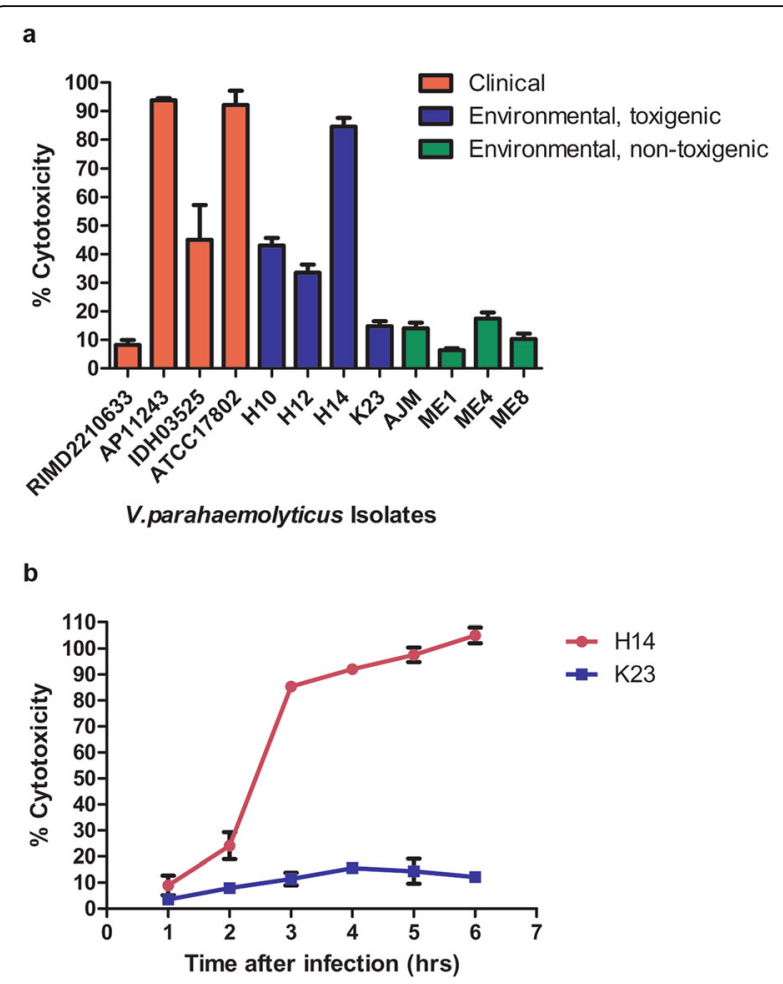

Fig. 2 LDH cytotoxicity assay. a Percentage of cytotoxic activity, as measured by LDH released from Caco-2 cells infected with clinical and environmental V.parahaemolyticus strains. The results represent the means of three independent determinations, performed six times \pm SE. $\mathbf{b}$ Time course analysis of cytotoxicity induced by H14 and K23. The results represent the means of two independent determinations $\pm \mathrm{SE}$, each performed in triplicate

Table 3 Adhesion and invasion indices of $V$. parahaemolyticus isolates

\begin{tabular}{lll}
\hline Strain ID & \multicolumn{2}{l}{ Average \pm SE (\%) } \\
\cline { 2 - 3 } & Adhesion Index & Invasion Index \\
\hline RIMD2210633 & $21.6 \pm 3.79$ & $0.008 \pm 0.001$ \\
AP11243 & $28.2 \pm 1.66$ & $0.12 \pm 0.018$ \\
IDH03525 & $22.3 \pm 5.54$ & $0.08 \pm 0.015$ \\
ATCC17802 & $8.62 \pm 2.81$ & $0.071 \pm 10.02$ \\
H10 & $16.9 \pm 2.41$ & $0.06 \pm 0.015$ \\
H12 & $9.75 \pm 0.25$ & $0.034 \pm 0.005$ \\
H14 & $26.9 \pm 1.02$ & $0.087 \pm 0.037$ \\
K23 & $23.1 \pm 2.03$ & $0.021 \pm 0.009$ \\
AJM & $18.1 \pm 1.9$ & $0.003 \pm 0.001$ \\
ME1 & $15.95 \pm 3.15$ & $0.014 \pm 0.007$ \\
ME4 & $11.4 \pm 3.9$ & $0.004 \pm 0.001$ \\
ME8 & $26.1 \pm 2.55$ & $0.12 \pm 0.069$ \\
S. Typhimurium & $30.8 \pm 2.85$ & $1.185 \pm 0.665$ \\
E. coli JM109 & $6.19 \pm 1.89$ & $0.004 \pm 0.0005$ \\
\hline
\end{tabular}

good adhesion ability of $\geq 22 \%$, except ATCC17802 (9\%). Irrespective of the toxigenic profile, the environmental isolates exhibited more than $15 \%$ adhesion to Caco- 2 cell with K23, H14 and ME8 (non-toxigenic) showing the maximum adhesion potential of 23, 27 and 26\%, respectively. This shows that environmental isolates adhered firmly to intestinal epithelial cells. There was no difference in adhesion among $t d h^{+}$and $t r h^{+}$pathotypes $(p>0.05$, Student's t-test) as well as between the different groups ( $p>0.05$, one-way ANOVA).

The ability of the selected $V$. parahaemolyticus isolates to invade Caco- 2 cells was determined using the classical gentamicin protection assay. Before the experiment, gentamicin MIC of all the isolates was determined using Etest $(\mathrm{MIC} \leq 4 \mu \mathrm{g} / \mathrm{ml})$.

Among the clinical isolates, AP11243 displayed the highest mean invasion index $(0.12 \%)$ followed by ATCC17802 (0.071\%) and IDH03525 (0.08\%) while RIMD2210633 showed very low invasion potential of $0.008 \%$ (Table 3, Fig. 3b). Of the toxigenic environmental isolates, $0.087 \%$ of $\mathrm{H} 14$ could invade Caco- 2 cells followed by $\mathrm{H} 10$ and H12. Again, K23, with a fully functional vopC (mediates invasion of non-phagocytic cells) displayed a lower invasion potential $(0.021 \%)$ compared to $t d h^{+} t r h^{-}$counterparts. Among the $t d h^{-} t r h^{-}$isolates, it was surprising to see the invasion index of ME8 was equal to that of AP11243 (0.12\%). The rest of the isolates were not invasive, except for ME1, which showed a slight invasion, when compared with the non-invasive control E. coli JM109 (Table 3). Here also, the results were not statistically significant between the various groups under study $(p>0.05)$.

An intracellular proliferation assay was done subsequently to know whether the toxigenic environmental isolates could persist and replicate intracellularly following invasion into the Caco- 2 cells. The experiment was done with the highly cytotoxic, adherent and invasive H14 $\left(t d h^{+} t r h^{-}\right)$and K23 $\left(t d h^{-} t r h^{+}\right)$, which has shown a lesser pathogenic potential in spite of having a complete T3SS. H14, and to a lesser extent, K23 rapidly proliferated inside Caco-2 cells (Fig. 3c). Peak numbers of H14 (450\% of initial intracellular CFU) was observed in about $3 \mathrm{~h}$. This number decreased rapidly and intracellular bacteria were still visible at $6 \mathrm{~h}$ of infection even though the levels were similar to that detected upon initial enumeration ( 100\%). Intracellular K23 also peaked at $3 \mathrm{~h}$ of infection, but the number of bacteria was lower (220\% of initial intracellular cfu) and at the end of $6 \mathrm{~h}$, the numbers declined. The decrease in intracellular bacteria could be attributed to the lysis of eukaryotic cells and subsequent killing in the gentamicin containing medium. We did observe rounding of cells by $2 \mathrm{~h}$ of incubation and detachment of cells from the 24-well plates by $6 \mathrm{~h}$, which made it impossible to prolong the experiment any further. 


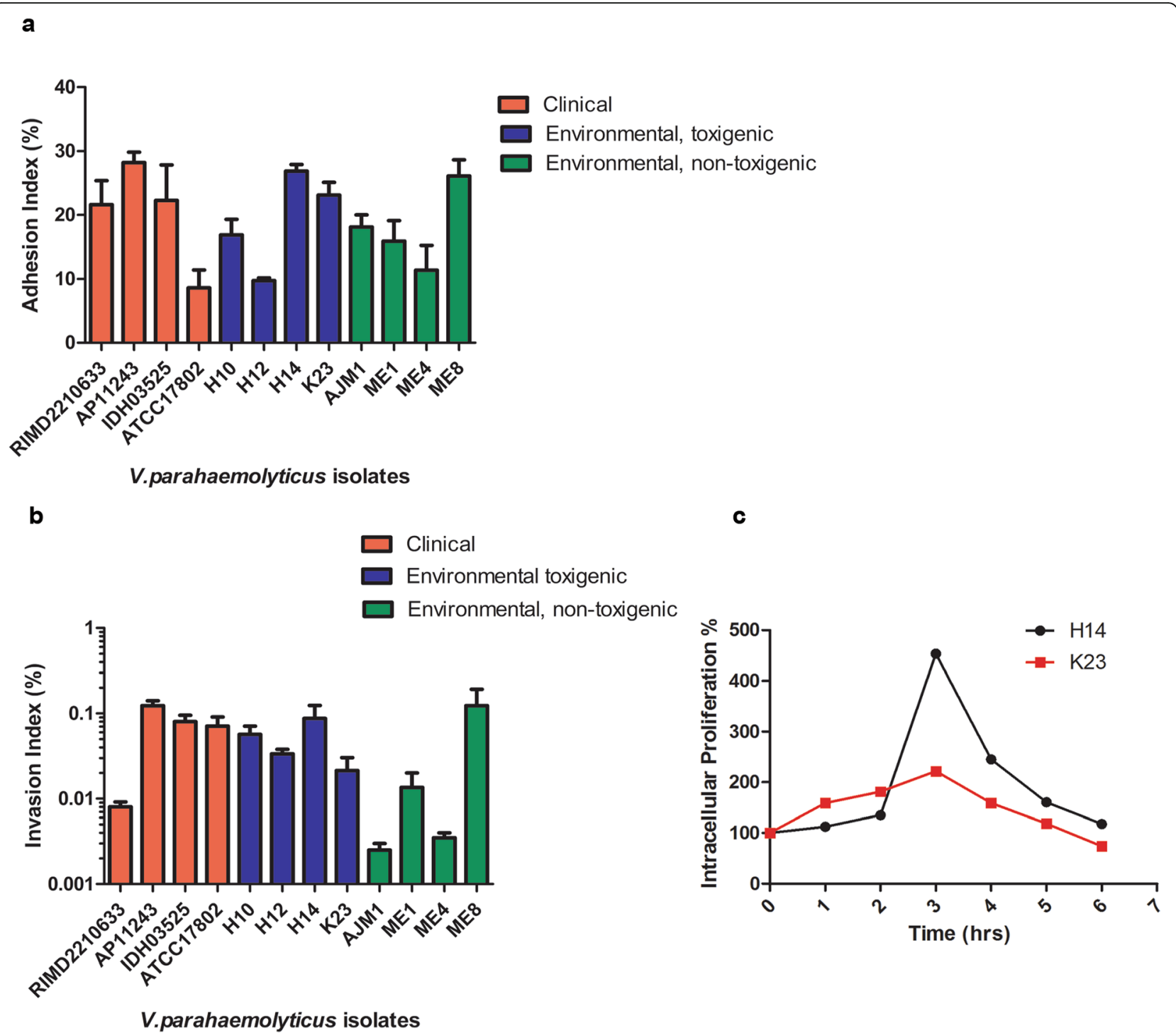

Fig. 3 Adhesion (a) and invasion (b) index of $V$. parahaemolyticus in Caco-2 cells. The values are means $\pm \mathrm{SE}$ of three independent experiments, each performed in triplicate. Adhesion and invasion indices between groups are not statistically significant $(p>0.05)$. c Intracellular proliferation assay of $V$. parahaemolyticus H14 and K23 in Caco-2 cells

\section{Alteration of ZO-1 and F-actin organisation by environmental $V$. parahaemolyticus}

$V$. parahaemolyticus has been known to compromise epithelial barrier integrity and associated disruption of actin and the tight junction proteins $[24,25]$. The effect of $\mathrm{H} 14$ and $\mathrm{K} 23$ on the localization of ZO-1 (a peripheral tight junction protein), and filamentous actin was examined using confocal microscopy. AP11243 was used as positive control strain as it showed more cytotoxicity and invasion potential than RIMD2210633. In uninfected cells, ZO-1 was located at the periphery and appeared as a continuous brightly stained band with a typical 'honey-comb structure' or 'chicken-wire pattern' revealing intact boundaries (Fig. 4). In cells infected with
AP11243, there was clear disruption of the monolayer, with visible strand breaks and punctate discontinuity. Infection with $t d h^{+} t r h^{-} \mathrm{H} 14$ isolate elicited a stronger disruption of ZO-1; large areas were seen where ZO-1 was completely displaced. In contrast, the $t d h^{-} t r h^{+} \mathrm{K} 23$ infected cells showed smaller but visible breaks, although the cell membrane integrity was preserved.

Actin filaments were visualised by fluorescently labelled bicyclic peptide, phalloidin that selectively binds to F-actin. Uninfected cells had branched, reticular actin network without any particular orientation. In contrast, AP11243 induced bundling of actin into long, parallel stress fibres. H14 infected cells had more number of such parallel arrays of F-actin. Surprisingly, cells infected 


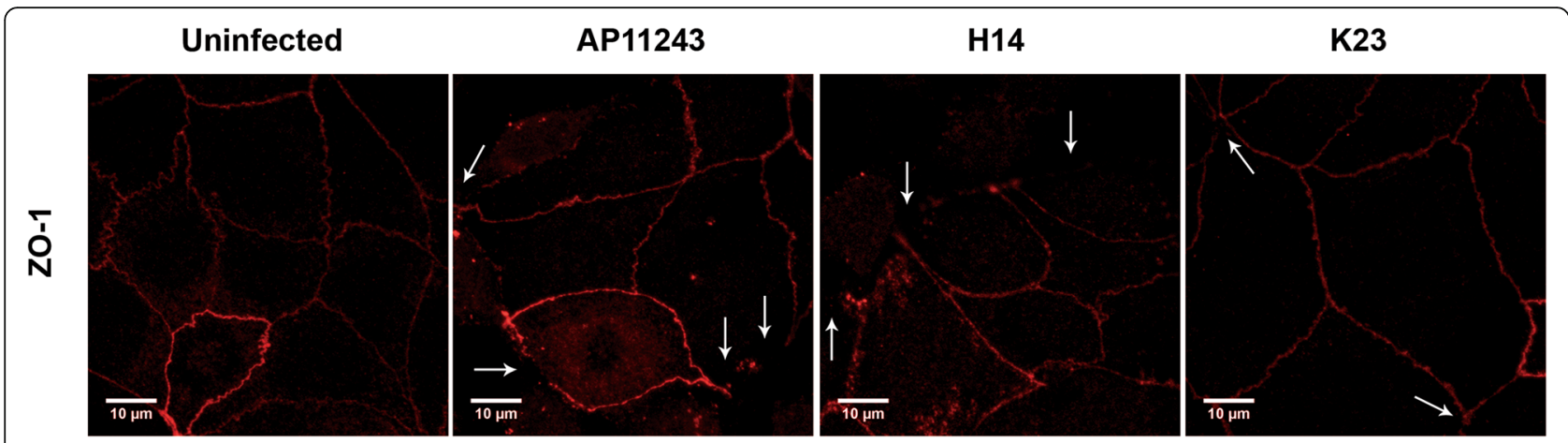

Fig. 4 ZO-1 redistribution in Caco-2 cells caused by V. parahaemolyticus environmental strains after $2 \mathrm{~h}$ of infection. Micrographs are representative of two separate experiments

with K23 depicted more prominent actin bundles that spanned the entire cell (Fig. 5).

\section{Discussion}

The present study examined the distribution of virulence related genes in $417 \mathrm{~V}$. parahaemolyticus isolated from the environment and seafood and focused on $t d h$ and/or trh isolates to determine the pathogenicity. An abundance of $V$. parahaemolyticus was seen in the water compared to plankton. This was in contrast to other studies where higher densities of $V$. parahaemolyticus were obtained from plankton [26, 27]. However, higher numbers of the bacterium were found in the Georgian coastal waters [28]. More than $5 \%$ of the $V$. parahaemolyticus isolates were potentially toxigenic, based on the presence of $t d h$ and $t r h$, of which $t d h$ was detected in a higher number of isolates (4.6\%). Previous studies from the south-west coast of India have reported a higher detection of trh-positive $V$. parahaemolyticus especially after $18 \mathrm{~h}$ of enrichment $[29,30]$. The toxigenic $V$. parahaemolyticus isolates obtained in this study were identified exclusively from seafood and none of the water and plankton isolates harboured the haemolysin genes. Hemolysin gene identification is partly dependent on the detection technique employed. The use of modified primers could recover 48 and $8 \% t d h$ and trh bearing isolates respectively from an estuarine system [31]. In another study, DePaola et al., tested a large number of colonies from oysters by DNA probes against th and $t d h$ and found that $21.8 \%$ of them were pathogenic [6]. Similarly, real time PCR could detect 20 and $40 \%$ more $t d h$ and trh positive $V$. parahaemolyticus from oyster samples and 13 and 40\% from water samples compared to the conventional techniques [32]. Thus, detection of toxigenic $V$. parahaemolyticus from environmental samples appears to be influenced by several factors.

T3SSs are an important determinant of pathogenicity of $V$. parahaemolyticus. All the toxigenic V. parahaemolyticus strains in this study carried the T3SS1 genes, consistent with previous reports $[17,33]$. The distribution of T3SS $2 \alpha$ genes was highly diverse with the loss of at least one gene from the $t d h^{+} t r h^{-}$isolates. Some of the isolates showed weak amplification with the T3SS2 $\alpha$ primer pair or additional primers designed. Jones et al. had also reported anomalies in the T3SS $2 \alpha$ gene amplification [33]. This suggests high sequence variability in environmental isolates or an absence of these genes due to partial uptake of $\mathrm{VPaI}$ during horizontal transfer. Further, vopB2 was present in $68.4 \%$ of $t d h^{+} t r h^{-}$isolates in contrast to earlier findings that it is associated with clinical and not environmental isolates [33, 34]. Some recent reports have documented the presence of $\operatorname{vop} B 2$ in environmental isolates $[35,36]$. Hence, vopB2 may not be a good indicator of virulence as originally suggested [34]. About $33 \%$ of $t d h^{+} t r h^{-}$isolates harboured vopZ gene that encodes the effector, VopZ, known for $V$. parahaemolyticus induced diarrhoea and intestinal pathology. To the best of our knowledge, this is the first study to document the presence of vopZ (VPA1336) in V. parahaemolyticus isolated from seafood.

Majority of the toxigenic isolates (95.5\%) had pandemic strain features $\left(\right.$ tox $\left.R S / \mathrm{new}^{+}\right)$. Of these, nine serovars (O1:K17, O1:K19, O1:K23, O10:K24, O2:KUT, O4: $\mathrm{K} 29$, O5:K20, O4:K42 and O4:K36) were newly identified with pandemic strain traits. Another striking observation is the appearance of $t d h^{-} t r h^{+}$isolates carrying the toxRS/ new $^{+}$pandemic marker. Pandemic strains of $V$. parahaemolyticus are mostly associated with the $t d h$ gene with few reports of GS-positive trh-containing isolates from clinical cases [23, 37, 38]. Data pertaining to the pandemic status of environmental trh-positive $V$. parahaemolyticus is lacking. Thus, this study is the first to report the isolation of a new serovar (O4:K36) of $t d h^{-} t r h^{+} V$. parahaemolyticus from seafood with potential pandemic traits. Currently the pandemic group is defined by the presence of $t d h$ and toxRS/new genes. So, the pandemic status and evolution of the three $t d h^{-} t r h^{+}$ isolates identified in this study should be confirmed 


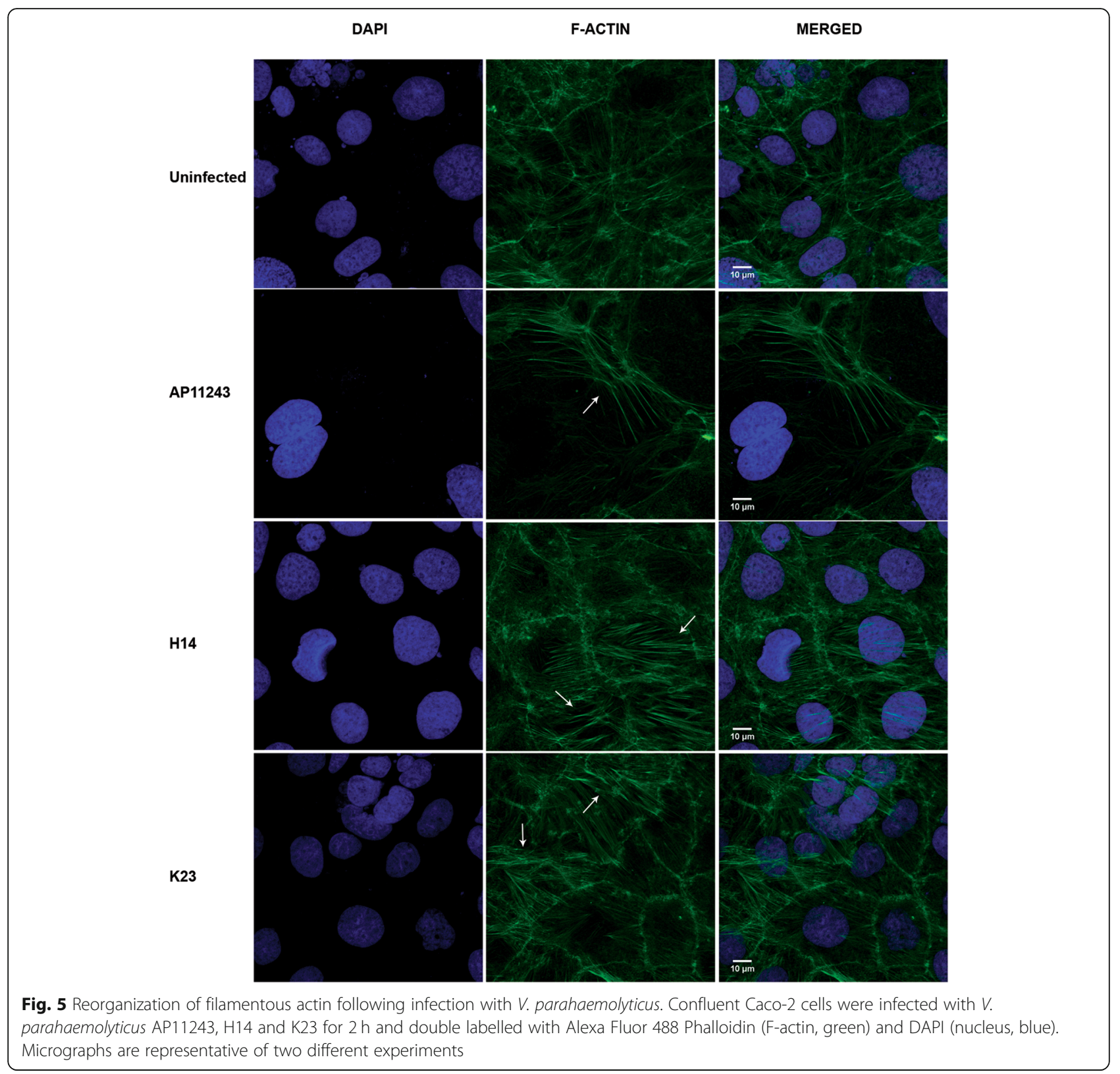

employing other genetic markers including genomic islands VPaI-1, VPaI-4 and VPaI-5 that are specific for the pandemic group [39-41] as well as whole genome sequence analysis. Besides, our finding of $t d h^{-} t r h^{+} \mathrm{O} 3$ : KUT serovar and its recent isolation from acute diarrhoea in India [23] underscores better cognizance of an epidemiological association between environmental and clinical strains.

Though considered a "gold standard", it is only recently that PFGE has been extensively employed for subtyping environmental strains of $V$. parahaemolyticus [8, 42, 43]. The PFGE pattern of the 15 isolates of this study showed considerable diversity and the new serovars having pandemic attributes were not related to the pandemic O3:K6 isolate. Further, it was noted that strains with identical serotype and/or genotype had different PFGE profiles, as in the case of $t d h^{+} t r h^{-}$isolates. Moreover, one of the O1:K25 isolate which was not positive in the GS-PCR, clustered along with the isolates having pandemic strain traits. A similar pattern was observed during molecular typing of $V$. parahemolyticus isolates in China, where seafood isolates having a varying combination of $t d h$, trh and toxRS/new genes clustered together with pandemic isolates whereas a $t d h^{+} t r h^{-}$, toxRS/new ${ }^{+}$clinical isolate was not genetically related to the pandemic clones [44]. Comparison of MLST datasets of different bacterial species revealed environmental isolates of marine and estuarine $V$. parahaemolyticus and 
$V$. vulnificus have very high homologous recombination rate as they frequently adapt for survival [45]. It was proposed that $V$. parahaemolyticus may have an epidemic population structure [46] where the isolates undergo frequent genetic recombination resulting in well-adapted clones [47]. Considering the increase in environmental strains acquiring virulence and pandemic attributes, it is important to know the genetics of this thriving population to reduce potential human health risk if newer virulent clones emerge.

To determine the pathogenic potential of environmental V. parahaemolyticus isolates, we used Caco- 2 cell line assays. As an initial step, the transcriptional activity of the haemolysin and T3SS2 effector genes were analysed in the selected isolates. While all the clinical strains transcribed both the haemolysin genes, only trh gene was functional in the environmental isolates. The expression results were substantiated by low haemolytic activity of the environmental isolates on human RBC. It is shown that poor expression of $t d h$ gene corresponds to two point mutations in the promoter region (substitution of A to $G$ in the -35 sequence, $G$ to $A$ at -3 nucleotide position from the -10 sequence) $[48,49]$. We presume that these mutations may be one of the reasons for the observed reduced transcription. Moreover, we found the isolates carried a single copy of $t d h$ (Additional file 1: Figure S4), which is generally responsible for weak and intermediate haemolysis due a weak promoter compared to $t d h 2$ [48]. The existence of a second copy of $t d h$ or mutations in the promoter needs to be further determined. Similarly, the low haemolytic activity of clinical as well as environmental $t d h^{-} t r h^{+}$isolates was not surprising as both contain the trh 2 allele (Additional file 1: Figure S4), which exhibit reduced hemolysis, not due to reduced gene expression, rather, owing to the differences in the amino acid molecular conformation and binding capacity of RBC by the trh 2 product [50, 51]. Further, the $t d h-t_{r h}{ }^{+}$environmental isolate $\mathrm{K} 23$ transcribed the genes vopC, vopA and vopL encoding effectors that promote invasion and modulate host cell behaviour, making it a possible pathogen. A similar functional T3SS2 $\beta$ was seen in trh-positive $V$. parahaemolyticus elsewhere in India [52].

Even though T3SS2 $\alpha$ was not functional in $t d h^{+} t r h^{-}$ environmental isolates, they were included in downstream analysis to know if the isolates could still induce any pathogenic effect. To begin with, we found all the isolates to be cytotoxic to Caco-2 cells without discernible differences in cytotoxicity between clinical and environmental isolates, as shown previously [53, 54]. Therefore, cytotoxicity may not be a reliable indicator of pathogenesis. It was also found that the ability to induce cytotoxicity was not dependent on the virulence genes tested. Interestingly, in the present investigation, the cytotoxicity of $t d h^{-} t r h^{+}$isolate K23 was very low compared to its clinical counterpart with a similar genetic profile. It is well established that T3SSs are responsible for host cell cytotoxic damage, with T3SS1 being the dominant contributor [55]. Perhaps the isolate might have a varied architecture and integrity of T3SS1 gene cluster causing it to assemble a defective translocon and a reduced delivery of T3SS1 effectors responsible for cytotoxicity. It is also possible that the clinical strain might harbour some exclusive genes not present in environmental isolate genome that can induce cytotoxic damage. Meanwhile, the cytotoxicity of the isolates that do not harbour virulence genes was noteworthy. There may be other yet unidentified genes contributing to host cytotoxicty and isolate-specific variations in the virulence of $V$. parahaemolyticus.

The environmental $V$. parahaemolyticus obtained in the study could adhere to and invade intestinal cell line, irrespective of the virulence profile. The ability of the representative $t d h$-positive (H14) and trh-positive (K23) isolates to invade was followed by survival and replication within the intracellular environment. Further, infection with $\mathrm{H} 14$ and $\mathrm{K} 23$ caused disruption of tight junctions and re-organisation of actin cytoskeleton, both of which can compromise the epithelial integrity. Recent research classifies $V$. parahaemolyticus as a facultative intracellular pathogen and T3SS2 effectors, VopC and VopL promote invasion and intracellular survival [56] in addition to inducing dramatic changes in the actin cytoskeleton along with VopV [57-59]. It was found that in spite of a functional vopC and a weakly transcribed vopL, H14 could still gain access to Caco- 2 cell, persist inside and induce changes on tight junctions and actin cytoskeleton. Burdette et al. [60] showed that T3SS1 also causes changes in actin cytoskeleton. The effects seen with the environmental strains may be due to an active T3SS1 albeit the contribution of T3SS2 effectors cannot be ignored, especially with $\mathrm{K} 23$, which can emerge as a potential pathogen and elicit a full blown pathogenic response under a favorable environment of host intestine. Moreover, the study detected a non-toxigenic isolate, ME8, from estuarine water exhibiting an invasive phenotype. Perhaps it may be the result of high levels of adhesion rather than active invasion. Recent studies have identified $t d h^{-} t r h^{-} V$. parahaemolyticus causing gastroenteritis [61-63], indicating the highly complex nature of the virulence of this pathogen.

\section{Conclusion}

This study is the first to extensively characterise the virulence, genetic diversity and elucidate the in-vitro pathogenic effects of $V$. parahaemolyticus isolated from Indian sub-continent. The results indicate the presence of new $V$. parahaemolyticus having pandemic traits from 
seafood that can adhere to, invade, replicate and cause structural changes in intestinal cell lines. In vivo studies are required to confirm enterotoxicity of these strains; yet, the demonstrated effects on intestinal cell line indicate their enhanced virulence potential. Attributing pathogenic potential for environmental isolates is an important aspect of understanding health risks associated with seafood borne $V$. parahaemolyticus. Although there have been significant progress in the virulence of $V$. parahaemolyticus, our data clearly indicate the difficulty in discriminating pathogenic and non-pathogenic $V$. parahaemolyticus with the current set of virulence genes, particularly when various pathotypes exist. We believe the concept of virulence in $V$. parahaemolyticus needs to be revisited and investigated for each pathotype. The threat of evolving pandemic and potentially pathogenic $V$. parahaemolyticus "environmental" strains looms on seafood consumers and thus, the need for dedicated $V$. parahaemolyticus surveillance programs in Indian marine and estuarine environment. Moreover, this is a reminder to strongly consider the bacterium in the event of a gastroenteritis outbreak.

\section{Methods}

\section{Sample collection, processing and identification of $V$.} parahaemolyticus

Environmental samples consisting of marine and estuarine water, plankton and different seafood were collected from several sampling sites during the period from 2012 to 2013, covering the coastal areas of Kerala. Samples were processed according to the American Public Health Association protocols [64] (see Additional file 1). For each sample, growth in alkaline peptone water (APW) was sub-cultured on thiosulfate citrate bile salt sucrose (TCBS) agar (HiMedia, Mumbai, India), incubated for $18-24 \mathrm{~h}$ at $37^{\circ} \mathrm{C}$. Presumptive isolates (non-sucrose fermenting green colonies) were identified by PCRs for species- specific toxR [65] and th [66] genes.

\section{Detection of virulence-associated genes}

The identified isolates were tested for the haemolysin genes $t d h$ and trh [66]. The pandemic strain marker genes were verified by GS- and ORF8-PCR [14, 15]. All the $t d h$ - and/or trh-positive isolates were further tested for the T3SS genes specific to T3SS1, T3SS2 $\alpha$ and T3SS2 $\beta$ (Additional file 1: Table S1). V. parahaemolyticus RIMD2210633 served as positive control for toxR, $t l h, t d h$, T3SS and T3SS2 $\alpha$ while ATCC17802 was used as the control for trh and T3SS2 $\beta$.

\section{Serogrouping}

Serological analysis of lipopolysaccharide (O) and capsular (K) antigens of $V$. parahaemolyticus was done using commercially available $V$. parahaemolyticus antisera kit (Denka Seiken, Tokyo, Japan) according to manufacturer's instructions.

\section{Pulsed-filed gel electrophoresis (PFGE)}

PFGE of $15 \mathrm{~V}$. parahaemolyticus toxigenic isolates belonging to diverse serovars was performed according to the standardised PulseNet protocol [67]. Salmonella enterica serovar Braenderup strain H9812 was used as a molecular weight marker. The PFGE profile of a clinical O3:K6 pandemic strain IDH2826 was included in the clonal comparison. The PFGE image was captured using a Gel Doc XR system (Bio-Rad Laboratories, Hercules, $\mathrm{CA}$ ), and the gel image was normalized by aligning the peaks of the XbaI (Takara, Shiga, Japan) size standards of S. Braenderup in each gel and was analyzed by using BioNumerics software version 4.0 (Applied Maths, SintMartens-Latem, Belgium). The similarities between isolates were evaluated by cluster analysis with the UPGMA method and the Dice correlation coefficient with a position tolerance of $1.5 \%$.

\section{Reverse transcriptase (RT) PCR}

Bacteria were grown in LB broth with $3 \% \mathrm{NaCl}$ to their mid-logarithmic phase and the total RNA extracted with RNeasy mini kit (Qiagen, Valencia, CA, USA). The extracted RNA was reverse transcribed using HighCapacity cDNA Reverse Transcription Kit (Applied Biosystems, Foster City, CA, USA). The cDNA generated was used as a template for the PCR using respective T3SS primer pairs.

\section{Caco-2 cell culture}

Caco-2 (ATCC HTB37, RIKEN BioResource Center, Tsukuba, Japan) cells were grown in Dulbecco's Modified Eagle Medium (DMEM, Gibco, Carlsbad, CA, USA) comprising 10\% (v/v) Fetal Bovine Serum (FBS, PANBiotech, Aidenbach, Germany) and $100 \mu \mathrm{g} / \mathrm{ml}$ penicillinstreptomycin (Gibco). The cells were grown at $37^{\circ} \mathrm{C}$ with $5 \% \mathrm{CO}_{2}$ for $5-7$ days.

\section{Haemolysis assay}

Haemolysis assay of the $V$. parahaemolyticus isolates was performed as described previously [53] with slight modifications. Briefly, freshly drawn human erythrocytes were rinsed three times with sterile phosphate buffered saline (PBS) and resuspended in PBS to $4 \%(\mathrm{v} / \mathrm{v})$. About $100 \mu \mathrm{l}$ of the suspension was mixed with an overnight culture of bacteria in LB broth- $3 \% \mathrm{NaCl}\left(3 \mathrm{X} 10^{8} \mathrm{cfu} / \mathrm{ml}\right)$ and incubated at $37^{\circ} \mathrm{C}$ for $6 \mathrm{~h}$ and $12 \mathrm{~h}$. Subsequently, the plates were centrifuged and the haemoglobin released was estimated by measuring the absorbance of the supernatant at $415 \mathrm{~nm}\left(\mathrm{OD}_{415}\right)$. PBS and $20 \%(\mathrm{v} / \mathrm{v})$ Triton-X 100 were used to determine the maximum and 
spontaneous haemoglobin release. The experiment was performed twice with six technical replicates. Percentage of haemolysis was expressed by the formula given below.

$\%$ hemolysis $=\frac{O D_{415} \text { for experimental release }-O D_{415} \text { for spontaneous release }}{O D_{415} \text { for maximum release }-O D_{415} \text { for spontaneous release }} \times 100$

\section{Cytotoxicity test}

Bacteria were grown in $\mathrm{LB}-3 \% \mathrm{NaCl}$ at $37^{\circ} \mathrm{C}$ overnight with shaking. Caco-2 cells were seeded in 96-well plates and grown until confluent. Three different wells with Caco-2 cell monolayers were co-cultured with PBSwashed bacteria at a multiplicity of infection (MOI) of 100:1 for $4 \mathrm{~h}$. The release of lactate dehydrogenase (LDH) into the medium was quantified using Cytotox96 non-radioactive cytotoxicity kit (Promega, Madison, WI, USA), following manufacturer's instructions. The LDH release (\% cytotoxicity) was calculated according to the formula:

$\%$ Cytotoxicity $=\frac{O D_{490} \text { for experimental release- } O D_{490} \text { for spontaneous release }}{O D_{490} \text { for maximum release- } O D_{490} \text { for spontaneous release }} \times 100$

The spontaneous release was the amount of LDH released from the cytoplasm of uninfected cells, whereas the maximum release was the amount of LDH released by total lysis of uninfected cells. The assay was replicated three times. A time course analysis of H14 and K23 cytotoxicity was also made at $1,2,3,4,5$ and 6 h post infection.

\section{Adhesion and invasion assays}

Adherence and invasion of $V$. parahaemolyticus were determined simultaneously [68] with modifications. In brief, $5 \times 10^{5}$ Caco- 2 cells were seeded and grown to confluence in 24-well tissue culture plates. PBS washed bacteria was added at an MOI of 10:1 to the confluent monolayer and incubated at $37^{\circ} \mathrm{C}$ for $2 \mathrm{~h}$ at $5 \% \mathrm{CO}_{2}$. Infected monolayers were washed thrice with PBS and lysed using 0.1\% Triton X-100 (Sigma-Aldrich, St Louis, MO, USA). Aliquots of the appropriate dilutions of the lysate were plated on LB with or without $3 \% \mathrm{NaCl}$ and incubated overnight at $37^{\circ} \mathrm{C}$ to count total adherent bacteria $\left(\mathrm{CFU} \mathrm{ml}{ }^{-1}\right)$. Adhesion efficiency was calculated as the total number of bacteria adhered expressed as a percentage of the number of bacteria in the original inoculum. For determining bacterial invasion, the infected monolayers were washed with PBS and further incubated for $1 \mathrm{~h}$ in DMEM containing $50 \mu \mathrm{g} / \mathrm{ml}$ gentamicin (Sigma) to kill the extracellular bacteria. After washing thrice, the monolayers were lysed and bacterial cells quantified. For each isolate, invasiveness was measured as the invasion index, which is the number of invaded organisms taken as a percentage of the number of adhered bacterial cells. The experiments were repeated three times and SEM was calculated. $S$. enterica serovar Typhimurium and E. coli JM109 were used as positive and negative controls. Isolates were scored as adherent or invasive if their index was more than that of E. coli JM109.

For the measurement of bacterial intracellular proliferation, invasion assay was carried out as above. After killing extracellular bacteria, the DMEM $+50 \mu \mathrm{g} / \mathrm{ml}$ gentamicin was removed and DMEM $+10 \mu \mathrm{g} / \mathrm{ml}$ gentamicin was added. At time points following the addition of DMEM-gentamicin mixture, cells were lysed and bacteria quantified. Proliferation was determined by calculating the percentage of the initial colony forming units (the point at which DMEM - gentamicin mixture was added) present at each time point.

\section{Fluorescence microscopy}

Caco-2 cells were seeded onto type I collagen-coated $(0.01 \%$, Sigma) coverslips in 6 -well plate and grown till confluent. Cells were infected with an overnight culture of bacteria grown in LB broth with $3 \% \mathrm{NaCl}$ at an MOI of $10: 1$ and incubated at $37^{\circ} \mathrm{C}$ for $2 \mathrm{~h}$. Following infection, coverslips were washed with PBS and fixed in $4 \%$ para-formaldehyde, after which the cells were rinsed with PBS supplemented with $0.1 \%$ Triton X-100 before being blocked for $1 \mathrm{~h}$ with $10 \%$ FBS and $0.1 \%$ Triton X100. The cells were incubated overnight with rabbit anti zonula occludin protein 1 (ZO-1, N-term) (Invitrogen, Carlsbad, CA, USA) in blocking buffer. The cells were washed with PBS and labelled with Alexa-Fluor 568 goat anti-rabbit antibody (Molecular Probes, ThermoFisher Scientific, Waltham, MA, USA) in blocking buffer for 1 h. The coverslips were then stained with 4',6-diamidino2-phenylindole (DAPI) for $10 \mathrm{~min}$, dried and coated with Fluoromount-G (EMS, Hatfield, PA, USA). For visualizing F-actin, cells were stained with Alexa-Fluor 488 phalloidin (Molecular Probes) after permeabilisation, and counterstained with DAPI. Images were captured with Leica TCS WLL SP8 confocal laser scanning microscope at $40 \mathrm{X}$ or $60 \mathrm{X}$ magnification with voltage and intensity kept constant and are presented as maximum intensity projections from Z-stacks. Images were processed using Image $(\mathrm{NIH})$.

\section{Statistics}

The significance of differences between groups was assessed using Student's t-test or one way analysis of variance (ANOVA) with Tukey's multiple comparison test using GraphPad Prism version 5.0 (GraphPad Software, San-Diego, CA, USA). $p<0.05$ was considered statistically significant. 


\section{Supplementary information}

Supplementary information accompanies this paper at https://doi.org/10. 1186/s12866-020-01746-2.

Additional file 1: Supplementary method. Table S1. Primers and annealing temperatures ( $\mathrm{Ta}$ ) used to characterize $V$. parahaemolyticus isolates. Figure S1. Transcription of trh. Figure S2. Hemolytic activity of $V$. parahaemolyticus isolates on human RBC. Figure S3. Transcription of T3SS genes. Figure S4. Partial amino acid sequence alignment of TDH (A) and $\mathrm{TRH}(\mathrm{B})$.

\section{Abbreviations}

ANOVA: Analysis of variance; CFU: Colony forming units; GS-PCR: Group specific polymerase chain reaction; LDH: Lactate dehydrogenase; NICED: National Institute of Cholera and Enteric Diseases; OD: Optical density; ORF: Open reading frame; PFGE: Pulsed-field gel electrophoresis; SE: Standard error; T3SS: Type III secretion system; TDH: Thermostable-direct hemolysin; TRH: TDH-related hemolysin; UPGMA: Unweighted pair group method with arithmetic mean; ZO-1: Zona occludens 1

\section{Acknowledgements}

DMP acknowledges the Indian Council of Medical Research, Government of India for the fellowship provided. We thank the team of National Institute of Cholera and Enteric Diseases (NICED), Kolkata, India for assistance with PFGE. We also thank Anurup K.G., RGCB for technical assistance with confocal microscopy. We are grateful to Prof. M. Radhakrishna Pillai, Director, RGCB for the facilities provided.

\section{Authors' contributions}

DMP and ST conceived and designed the experiments. DMP performed the experiments and drafted the manuscript. DMP and ST analysed the results. TR and ST critically reviewed the manuscript. All authors read and approved the final manuscript.

\section{Funding}

The authors received no specific funding for this work.

\section{Availability of data and materials}

The datasets used and/or analysed during the current study are available from the corresponding author on reasonable request.

\section{Ethics approval and consent to participate}

Not applicable.

\section{Consent for publication}

Not applicable.

\section{Competing interests}

The authors declare that they have no competing interests.

\section{Author details}

${ }^{1}$ Cholera and Biofilm Research Lab, Department of Pathogen Biology, Rajiv Gandhi Centre for Biotechnology, Thiruvananthapuram, Kerala 695 014, India. ${ }^{2}$ Centre for Human Microbial Ecology, Translational Health Science and Technology Institute, Faridabad, India.

Received: 23 July 2019 Accepted: 5 March 2020

Published online: 23 March 2020

References

1. Fujino T. On the bacteriological examination of shirasu food poisoning. Med J Osaka Univ. 1953;4:299-304

2. Daniels NA, MacKinnon L, Bishop R, Altekruse S, Ray B, Hammond RM, et al. Vibrio parahaemolyticus infections in the United States, 1973-1998. J Infect Dis. 2000;181:1661-6.

3. Honda T, lida T. The pathogenicity of Vibrio parahaemolyticus and the role of the thermostable direct haemolysin and related haemolysins. Rev Med Microbiol. 1993;4:106-13.

4. Shirai $\mathrm{H}$, Ito H, Hirayama $T$, Nakamoto $Y$, Nakabayashi N, Kumagai $K$, et al. Molecular epidemiologic evidence for association of thermostable direct hemolysin (TDH) and TDH-related hemolysin of Vibrio parahaemolyticus with gastroenteritis. Infect Immun. 1990:58:3568-73.

5. Makino K, Oshima K, Kurokawa K, Yokoyama K, Uda T, Tagomori K, et al. Genome sequence of Vibrio parahaemolyticus: a pathogenic mechanism distinct from that of Vibrio cholerae. Lancet. 2003;361:743-9.

6. DePaola A, Ulaszek J, Kaysner CA, Tenge BJ, Nordstrom JL, Wells J, et al. Molecular, serological, and virulence characteristics of Vibrio parahaemolyticus isolated from environmental, food, and clinical sources in North America and Asia. Appl Environ Microbiol. 2003;69:3999-4005.

7. Nordstrom JL, Vickery MCL, Blackstone GM, Murray SL, DePaola A. Development of a multiplex real-time PCR assay with an internal amplification control for the detection of total and pathogenic Vibrio parahaemolyticus bacteria in oysters. Appl Environ Microbiol. 2007;73: 5840-7

8. Chen AJ, Hasan NA, Haley BJ, Taviani E, Tarnowski M, Brohawn K, et al. Characterization of pathogenic Vibrio parahaemolyticus from the Chesapeake Bay, Maryland. Front Microbiol. 2017:8:2460.

9. Okada N, lida T, Park KS, Goto N, Yasunaga T, Hiyoshi H, et al. Identification and characterization of a novel type III secretion system in trh-positive Vibrio parahaemolyticus strain TH3996 reveal genetic lineage and diversity of pathogenic machinery beyond the species level. Infect Immun. 2009:77: 904-13.

10. Caburlotto G, Gennari M, Ghidini V, Tafi M, Lleo MM. Presence of T3SS2 and other virulence-related genes in tdh-negative Vibrio parahaemolyticus environmental strains isolated from marine samples in the area of the venetian lagoon, Italy. FEMS Microbiol Ecol. 2009;70:506-14.

11. Chen X, Zhu Q, Yu F, Zhang W, Wang R, Ye X, et al. Serology, virulence and molecular characteristics of Vibrio parahaemolyticus isolated from seafood in Zhejiang province. PLoS One. 2018;13:e0204892.

12. Okuda J, Ishibashi M, Hayakawa E, Nishino T, Takeda Y, Mukhopadhyay AK, et al. Emergence of a unique O3:K6 clone of Vibrio parahaemolyticus in Calcutta, India, and isolation of strains from the same clonal group from southeast Asian travelers arriving in Japan. J Clin Microbiol. 1997;35:3150-5.

13. Nair GB, Ramamurthy T, Bhattacharya SK, Dutta B, Takeda Y, Sack DA. Global dissemination of Vibrio parahaemolyticus serotype O3:K6 and its serovariants. Clin Microbiol Rev. 2007:20:39-48.

14. Matsumoto C, Okuda J, Ishibashi M, Iwanaga M, Garg P, Rammamurthy T, et al. Pandemic spread of an 03: K6 clone of Vibrio parahaemolyticus and emergence of related strains evidenced by arbitrarily primed PCR and toxRS sequence analyses. J Clin Microbiol. 2000;38:578-85.

15. Laohaprertthisan V, Chowdhury A, Kongmuang U, Kalnauwakul S, Ishibashi M, Matsumoto $C$, et al. Prevalence and serodiversity of the pandemic clone among the clinical strains of Vibrio parahaemolyticus isolated in southern Thailand. Epidemiol Infect. 2003;130:395-406.

16. Chen J, Zhang R, Qi X, Zhou B, Wang J, Chen Y, et al. Epidemiology of foodborne disease outbreaks caused by Vibrio parahaemolyticus during 2010-2014 in Zhejiang Province, China. Food Control. 2017:77:110-5.

17. Li H, Tang R, Lou Y, Cui Z, Chen W, Hong Q, et al. A comprehensive epidemiological research for clinical Vibrio parahaemolyticus in Shanghai. Front Microbiol. 2017;8:1043

18. Park K, Mok JS, Kwon JY, Ryu AR, Kim SH, Lee HJ. Food-borne outbreaks, distributions, virulence, and antibiotic resistance profiles of Vibrio parahaemolyticus in Korea from 2003 to 2016: a review. Fish Aquat Sci. 2018; 21:3.

19. Newton AE, Garrett N, Stroika S, Halpin UL, Turnsek M, Mody R. Increase in Vibrio parahaemolyticus infections associated with consumption of Atlantic Coast shellfish - 2013. MMWR Morb Mortal Wkly Rep. 2014;63:335-6.

20. Taylor M, Cheng J, Sharma D, Bitzikos O, Gustafson R, Fyfe M, et al. Outbreak of Vibrio parahaemolyticus associated with consumption of raw oysters in Canada, 2015. Foodborne Pathog Dis. 2018;15:554-9.

21. Baker-Austin C, Stockley L, Rangdale R, Martinez-Urtaza J. Environmental occurrence and clinical impact of Vibrio vulnificus and Vibrio parahaemolyticus: a European perspective. Environ Microbiol Rep. 2010;2:7-18.

22. Martinez-Urtaza J, Powell A, Jansa J, Rey JLC, Montero OP, Campello MG, et al. Epidemiological investigation of a foodborne outbreak in Spain associated with U.S. West Coast genotypes of Vibrio parahaemolyticus. Springerplus. 2016;5:87

23. Pazhani GP, Bhowmik SK, Ghosh S, Guin S, Dutta S, Rajendran K, et al. Trends in the epidemiology of pandemic and non-pandemic strains of Vibrio parahaemolyticus isolated from diarrheal patients in Kolkata, India. PLoS Negl Trop Dis. 2014;8:e2815. 
24. Lynch T, Livingstone S, Buenaventura E, Fedwick J, Buret AG, Graham D, et al. Vibrio parahaemolyticus disruption of epithelial cell tight junctions occurs independently of toxin production. Infect Immun. 2005:73:1275-83.

25. Ritchie JM, Rui H, Zhou X, lida T, Kodoma T, Ito S, et al. Inflammation and disintegration of intestinal villi in an experimental model for Vibrio parahaemolyticus-induced diarrhea. PLoS Pathog. 2012;8:e1002593.

26. Sarkar BL, Nair GB, Banerjee AK, Pal SC. Seasonal distribution of Vibrio parahaemolyticus in freshwater environs and in association with freshwater fishes in Calcutta. Appl Environ Microbiol. 1985;49:132-6.

27. Chowdhury MAR, Yamanaka H, Miyoshi S, Shinoda S. Ecology and seasona distribution of Vibrio parahaemolyticus in aquatic environments of a temperate region. FEMS Microbiol Lett. 1990;74:1-9.

28. Haley BJ, Kokashvili T, Tskshvediani A, Janelidze N, Mitaishvili N, Grim CJ, et al. Molecular diversity and predictability of Vibrio parahaemolyticus along the Georgian coastal zone of the Black Sea. Front Microbiol. 2014;5:45.

29. Deepanjali A, Kumar HS, Karunasagar I, Karunasagar I. Seasonal variation in abundance of total and pathogenic Vibrio parahaemolyticus bacteria in oysters along the southwest coast of India. Appl Environ Microbiol. 2005;71: 3575-80.

30. Parvathi A, Kumar HS, Bhanumathi A, Ishibashi M, Nishibuchi M, Karunasagar I, et al. Molecular characterization of thermostable direct haemolysin-related haemolysin (TRH)-positive Vibrio parahaemolyticus from oysters in Mangalore, India. Environ Microbiol. 2006;8:997-1004

31. Gutierrez West CK, Klein SL, Lovell CR. High frequency of virulence factor genes $t d h$, trh, and th in Vibrio parahaemolyticus strains isolated from a pristine estuary. Appl Environ Microbiol. 2013;79:2247-52.

32. Parveen S, Hettiarachchi KA, Bowers JC, Jones JL, Tamplin ML, McKay R, et al. Seasonal distribution of total and pathogenic Vibrio parahaemolyticus in Chesapeake Bay oysters and waters. Int J Food Microbiol. 2008;128:354-61.

33. Jones JL, Lüdeke CHM, Bowers JC, Garrett N, Fischer M, Parsons MB, et al. Biochemical, serological, and virulence characterization of clinical and oyster Vibrio parahaemolyticus isolates. J Clin Microbiol. 2012;50: 2343-52.

34. Noriea NF, Johnson CN, Griffitt KJ, Grimes DJ. Distribution of type III secretion systems in Vibrio parahaemolyticus from the northern Gulf of Mexico. J Appl Microbiol. 2010;109:953-62.

35. Paranjpye R, Hamel OS, Stojanovski A, Liermann M. Genetic diversity of clinical and environmental Vibrio parahaemolyticus strains from the Pacific northwest. Appl Environ Microbiol. 2012;78:8631-8.

36. Gao L, Deng YQ, Chen C, Ke CW, Li BS, Long YY, et al. Population relationship of Vibrio parahaemolyticus isolates derived from aquaculture ponds, a seafood market, restaurants, and clinical samples. Foodborne Pathog Dis. 2016;13:333-42.

37. Meador CE, Parsons MM, Bopp CA, Gerner-Smidt P, Painter JA, Vora GJ. Virulence gene- and pandemic group-specific marker profiling of clinical Vibrio parahaemolyticus isolates. J Clin Microbiol. 2007:45:1133-9.

38. Li J, Xue F, Yang Z, Zhang X, Zeng D, Chao G, et al. Vibrio parahaemolyticus strains of pandemic serotypes identified from clinical and environmental samples from Jiangsu, China. Front Microbiol. 2016;7:787.

39. Hurley CC, Quirke A, Reen FJ, Boyd EF. Four genomic islands that mark post1995 pandemic Vibrio parahaemolyticus isolates. BMC Genomics. 2006;7:104.

40. Chao G, Jiao X, Zhou X, Yang Z, Pan Z, Huang J, et al. Systematic functional pandemic strain-specific genes, three genomic islands, two T3SSs in foodborne, and clinical Vibrio parahaemolyticus isolates in China. Foodborne Pathog Dis. 2009;6:689-98.

41. Chao G, Jiao X, Zhou X, Wang F, Yang Z, Huang J, et al. Distribution of genes encoding four pathogenicity islands (VPals), T6SS, biofilm, and type pilus in food and clinical strains of Vibrio parahaemolyticus in China. Foodborne Pathog Dis. 2010;7:649-58.

42. Terzi Gulel G, Martinez-Urtaza J. Molecular characterizations of Vibrio parahaemolyticus in seafood from the Black Sea, Turkey. Lett Appl Microbiol. 2016:62:494-500

43. Lopatek M, Wieczorek K, Osek J. Antimicrobial resistance, virulence factors, and genetic profiles of Vibrio parahaemolyticus from seafood. Appl Environ Microbiol. 2018:84:e00537-18.

44. Chen W, Xie Y, Xu J, Wang Q, Gu M, Yang J, et al. Molecular typing of Vibrio parahaemolyticus isolates from the middle-east coastline of China. Int J Food Microbiol. 2012;153:402-12.

45. Vos $M$, Didelot $X$. A comparison of homologous recombination rates in bacteria and archaea. ISME J. 2009;3:199-208.
46. Gonzalez-Escalona N, Martinez-Urtaza J, Romero J, Espejo RT, Jaykus L-A DePaola A. Determination of molecular phylogenetics of Vibrio parahaemolyticus strains by multilocus sequence typing. J Bacteriol. 2008; 190:2831-40.

47. Smith JM, Feil EJ, Smith NH. Population structure and evolutionary dynamics of pathogenic bacteria. BioEssays. 2000;22:1115-22.

48. Okuda J, Nishibuchi M. Manifestation of the Kanagawa phenomenon, the virulence-associated phenotype of Vibrio parahaemolyticus depends on a particular single base change in the promoter of the thermostable direct haemolysin gene. Mol Microbiol. 1998:30:499-511.

49. Shalu OA, Pisanov RV, Monakhova EV. Efficiency of Vibrio parahaemolyticus tdh gene expression depends upon two point mutations in its promoter region. Russ J Genet. 2012;48:1177-83.

50. Kishishita M, Matsuoka N, Kumagai K, Yamasaki S, Takeda Y, Nishibuchi M. Sequence variation in the thermostable direct hemolysin-related hemolysin (trh) gene of Vibrio parahaemolyticus. Appl Environ Microbiol. 1992;58:2449-57.

51. Bechlars S, Jäckel C, Diescher S, Wüstenhagen DA, Kubick S, Dieckmann R, et al. Characterization of trh2 harbouring Vibrio parahaemolyticus strains isolated in Germany. PLoS One. 2015;10:e0118559.

52. Kumar BK, Deekshit VK, Rai P, Shekar M, Karunasagar I, Karunasagar I. Presence of T3SS2 $\beta$ genes in $\mathrm{trh}^{+}$Vibrio parahaemolyticus isolated from seafood harvested along Mangalore coast, India. Lett Appl Microbiol. 2014; $58: 440-6$

53. Mahoney JC, Gerding MJ, Jones SH, Whistler CA. Comparison of the pathogenic potentials of environmental and clinical Vibrio parahaemolyticus strains indicates a role for temperature regulation in virulence. Appl Environ Microbiol. 2010;76:7459-65.

54. Caburlotto G, Lleò MM, Hilton T, Huq A, Colwell RR, Kaper JB. Effect on human cells of environmental Vibrio parahaemolyticus strains carrying type III secretion system 2. Infect Immun. 2010;78:3280-7.

55. Hiyoshi H, Kodama T, lida T, Honda T. Contribution of Vibrio parahaemolyticus virulence factors to cytotoxicity, enterotoxicity, and lethality in mice. Infect Immun. 2010:78:1772-80.

56. de Souza SM, Orth K. Intracellular Vibrio parahaemolyticus escapes the vacuole and establishes a replicative niche in the cytosol of epithelial cells. MBio. 2014:5:e01506-14

57. Liverman ADB, Cheng H-C, Trosky JE, Leung DW, Yarbrough ML, Burdette $D L$, et al. Arp2/3-independent assembly of actin by Vibrio type III effector VopL. Proc Natl Acad Sci U S A. 2007;104:17117-22.

58. Hiyoshi H, Kodama T, Saito K, Gotoh K, Matsuda S, Akeda Y, et al. VopV, an F-actin-binding type III secretion effector, is required for Vibrio parahaemolyticus-induced enterotoxicity. Cell Host Microbe. 2011;10:401-9.

59. Zhang L, Krachler AM, Broberg CA, Li Y, Mirzaei H, Gilpin CJ, et al. Type III effector VopC mediates invasion for Vibrio species. Cell Rep. 2012;1: 453-60.

60. Burdette DL, Yarbrough ML, Orvedahl A, Gilpin CJ, Orth K. Vibrio parahaemolyticus orchestrates a multifaceted host cell infection by induction of autophagy, cell rounding, and then cell lysis. Proc Natl Acad Sci U S A. 2008;105:12497-502.

61. García K, Torres R, Uribe P, Hernández C, Rioseco ML, Romero J, et al. Dynamics of clinical and environmental Vibrio parahaemolyticus strains during seafood-related summer diarrhea outbreaks in southern Chile. App Environ Microbiol. 2009;75:7482-7.

62. Ottaviani $D$, Leoni F, Serra R, Serracca L, Decastelli L, Rocchegiani E, et al. Nontoxigenic Vibrio parahaemolyticus strains causing acute gastroenteritis. J Clin Microbiol. 2012:50:4141-3.

63. Banerjee SK, Kearney AK, Nadon CA, Peterson C-L, Tyler K, Bakouche L, et al. Phenotypic and genotypic characterization of Canadian clinical isolates of Vibrio parahaemolyticus collected from 2000 to 2009. J Clin Microbiol. 2014; 52:1081-8.

64. Lear DW. Field methodology. In: Greenberg AE, Hunt DA, editors. Laboratory procedures for the examination of seawater and shellfish. Washington DC: American Public Health Association; 1984.p. 18-36.

65. Kim YBU, Okuda JUN, Matsumoto C, Takahashi N, Hashimoto S, Nishibuch M. Identification of Vibrio parahaemolyticus strains at the species level by PCR targeted to the toxR gene. 1999;37:1173-7.

66. Bej AK, Patterson DP, Brasher CW, Vickery MCL, Jones DD, Kaysner CA. Detection of total and hemolysin-producing Vibrio parahaemolyticus in shellfish using multiplex PCR amplification of $t 1$, tdh and trh. J Microbiol Methods. 1999;36:215-25. 
67. Kam KM, Luey CKY, Parsons MB, Cooper KLF, Nair GB, Alam M, et al. Evaluation and validation of a PulseNet standardized pulsed-field ge electrophoresis protocol for subtyping Vibrio parahaemolyticus: an international multicenter collaborative study. J Clin Microbiol. 2008;46: 2766-73.

68. Elsinghorst EA, Kopecko DJ. Molecular cloning of epithelial cell invasion determinants from enterotoxigenic Escherichia coli. Infect Immun. 1992;60: 2409-17.

\section{Publisher's Note}

Springer Nature remains neutral with regard to jurisdictional claims in published maps and institutional affiliations.

- fast, convenient online submission

- thorough peer review by experienced researchers in your field

- rapid publication on acceptance

- support for research data, including large and complex data types

- gold Open Access which fosters wider collaboration and increased citations

- maximum visibility for your research: over $100 \mathrm{M}$ website views per year

At BMC, research is always in progress.

Learn more biomedcentral.com/submissions 